\title{
The Application of Confucianism in Modern Furniture Industry
}

\author{
Liang Zhang, a , Jian Zhao, b and Linan Zheng ${ }^{1, c}$ \\ ${ }^{1}$ Qingdao Binhai University, Qingdao, Shandong, China \\ a76201691@qq.com, $84310626 @ q q . c o m,{ }^{\mathrm{c}} 1021090387 @ q q . c o m$
}

Keywords: Innovation; National culture; Confucianism; Furniture industry

\begin{abstract}
The reason why many countries in the world have attracted worldwide attention in the field of product design, it is not just the technology progress plays an important role but the design innovation is frequently more important. In today's society, innovative design thinking largely determines the design achievement, and this thought often deeply rooted in the national culture. Drawing inspiration from Confucianism can be reflected in the furniture products with Neo Confucianism implication On one hand, on the other hand, through the application of Confucianism in the furniture industry can enhance national identity and national pride, thus constantly enhance Confucianism influence in today's social and achieve the purpose of national education.
\end{abstract}

\section{Introduction}

Due to the production of furniture industry in China for quick success, design copying each other, making serious homogenization in the furniture industry of our country caused by low value-added products, can not form a strong competitive scale, more can't be compared with similar products in developed countries, which seriously affected the furniture enterprises in our country's international standing[1].At present, the Chinese furniture industry should look to the future with broad vision, practical in our splendid culture and rich cultural heritage as the basis, continuous innovation and design, and strive to build with Chinese characteristics, modern furnishings. By studying Confucianism, the purpose of this paper is to explore the application of excellent national culture in modern furniture industry.

\section{The Present Situation and Developing Trend of Furniture Industry}

Although China's furniture industry is highly competitive, but the product quality is generally not high, the cult of the amount is much higher than the pursuit of the confrontation. Furniture industry relying on cheap labor resources, mainly in the form of OEM product expansion, heavy manufacturing and lightweight design, not to mention high-quality original design, the result is uneven product quality, it is difficult to form a strong furniture brand and high-quality specialty products [1].

In the future, the more localization and ethnic things, the more unique and grade, it is easier to form a strong competitive advantage, so with the development of society, the cultural characteristics of furniture products will become more and more prominent.

In order to create a national and cultural characteristics of the modern furniture products, a lot of people made some attempts, but they are more in product design so-called design innovation through stuffing, stitching and other traditional elements of symbolic way, in fact, this design means is still low level, will eventually fall into the quagmire of formalism [2], which not only can not stand the test of the market but more helpless to enhance the furniture industry product quality. For the application of traditional culture in the modern furniture industry, we need to define that "new Chinese" furniture design than the traditional symbol for plagiarism and is not a simple patchwork, but to highlight the cultural connotation and spiritual culture, especially a blend of traditional culture and modern culture, which pursuit is a source from the traditional but don't in the traditional sense, in order to reach a both familiar and strange aesthetic effect [3].

Therefore, to further study of Chinese traditional culture and truly understand the spiritual core of Chinese traditional culture, refining the design elements with national characteristics, from 
modeling to style, from structure to process, from materials to decorate on deep innovation design, truly establish the system of the "new Chinese" furniture to create a more cultural connotation of the characteristics of furniture products, it is the only way to truly make China furniture industry embarked on the road of independent innovation.

\section{The Products Design in Furniture Industry with New Confucianism}

Confucianism has a unique and pivotal position in China, on one hand it is believed to reflect the prevailing world view and outlook on life, on the other hand it is considered a master of Chinese philosophy, is the kernel of the spirit of our traditional culture. Confucianism, with its rich ideological resources and spiritual connotation, provides valuable resources for all aspects of today's society [4].

The so-called New Confucianism furniture design refers to both follow the basic core of Confucianism, but also combines industry trends, the social and cultural needs in furniture design. This article through to explore Confucianism and modern furniture design, from the three aspects of the concept of nature, Mean Thought, virtue and morality.

\section{New Confucianism Style Furniture Design and Natural Concept.}

In the Confucian classic "Rites" and "Research" chapter was advised to put forward opportune Handicraft concept, reflects the ancient naive view of nature and the idea of creation. Wherein the day, referring to the natural changes according to seasons and the Transformation Law, up with the time; location, refers to fully exploit the advantages of geographical conditions [5], the best use; harmonious, the emphasis is harmonious interpersonal and social relations stable, and this relationship is simple, pure, which is the day, geography regularity in the continuation of human society; appropriate, referring to the man-made and must follow the natural laws of physics in order to make the product more suitable for use; Handicraft, referring to the skilled craftsmen and cooked hundreds of workers and the artful. According to the ancient view of nature, only on the basis of natural law to follow on good research and development, in order to achieve Handicraft summarize results.

Thought of creation in ancient China not only far-reaching but also gain some achievements of classic, such as the furniture of Ming furniture is both a design model and also as a design with Chinese characteristics and a symbol of the prestigious, which is not only the reflection of Handicraft but also the wonderful expression of China's natural idea in the field of design. With Ming-style furniture as the representative of the Chinese style furniture follow our ideas on nature, inherit the spirit of traditional Chinese culture, intentions handle the relationship between people, objects, the environment, using a streamlined design art language, implicitly express things the connotation, the furniture tended to emphasize performance texture feature wood itself, without nail glue, clever use of the material itself to attain the structure of the connection, do not pursue additional decoration, modeling simple, elegant style, exquisite shape beauty, material beauty, arts crafts, artistic conception beauty, with the product has sculptural beauty [6-7].

Scarce resource in today's society, environmental degradation, the focus of resources, environmental protection has become an issue of common concern to human society. Environmental protection, low-carbon life, sustainable development and other issues not only affect every aspect of modern society, but also put forward new requirements for the design, which requires us in product design pay more attention to social issues and green furniture design concept is generated in this situation. Green design of furniture mainly follow the $3 \mathrm{R}$ principles, namely, reduce (reduce resource), reuse (reuse), recycle (recycling) [8], in addition the law of 3E has gradually attracted the more and more people's attention, the so-called $3 \mathrm{E}$ rule refers to equitable to reduce economic resources, it mainly to protect the environment, to human nature design. But no matter what kind of design principles, specific to the whole process of furniture design, green furniture is mainly reflected in the material, structure, craft, decoration, packaging, recycling and other aspects, so in the furniture design at the beginning you have to consider the recycling problem, 
and followed by material selection in furniture manufacturing process, selection of imported materials can be considered or that bamboo raw materials can also use uniform, environmentally friendly materials can be matched with the appropriate development of natural materials, in order to achieve the combination of traditional materials with modern materials and environmental protection purposes; in the production process, as far as possible the use of new technology to reduce waste, dust and noise etc., make the best use of them, really achieve the effect of sustainable development.

\section{New Confucianism Style Furniture Design and Mean Thought.}

Moderation is the essence of Confucianism, which emphasizes impartiality, compromise coordinated manner. Confucius stressed that "rites, harmony is the most precious", which is to ask to do things in moderation, excessive and insufficient are intolerable, to pursue the right with a common or usual attitude. In the treatment of modern furniture design problem, although the current popular design theories have advocated the combination of traditional culture and modern design, but the specific implementation process is very prone to two extremes, the one, over-reliance on traditional classics, lack of innovation, thereby lead to conformism; the Second, completely abandon the traditional, easily into the quagmire of formalism[9].Therefore, a combination of traditional and modern in the furniture industry is necessary under the influence of the doctrine of thought not only avoiding the blind innovation but also to critically inherit and develop the traditional cultural spirit of respect, the base being on the rational aesthetic, follow the basic law of development of human society, to explore the real needs of modern society, down to earth, targeted innovation. Modern furniture industry in the Mean Thought mainly in the following aspects:

Modeling Aspect. Modeling is the soul of furniture, but also the traditional cultural heritage in the most direct expression. Furniture can be made about the shape of the symbol from the traditional elements, decorative patterns, humanities and other aspects of scrutiny, the use of abstraction, generalization, a variety of means constituting the deformation, reconstruction and other traditional culture in order to give the new model, and strive to achieve both familiar and strange beauty. Danish designer Hans J. Wegner through in-depth study of Chinese culture and Chinese style furniture characteristics, using modern means of modeling, precise shaping the obvious characteristics of the Chinese chair series. which works to convey the feeling of oriental charm and become a modern Chinese furniture industry model of learning.

Structure Aspect. In today's society, the material and commercial characteristic is obvious, the blind pursuit of high efficiency and low cost makes the furniture production enterprise too worship mechanization of production capacity, reduce the number of traces of artificial, this makes in today's society, the furniture product structure is more and more simplified. On the other hand also caused the lack of traditional arts and crafts, which is the important reasons for China's modern furniture products lack of features. Only under the influence of the doctrine of the mean thought to coordinated development of mechanization and crafts to create high-quality furniture products. Traditional crafts have an immeasurable value, it is not only a part of the national culture but also the important means in highlight the national characteristics and improve the taste of products. the reason why Scandinavian design is world famous because they insisted on mechanization and crafts coexist, and innovation in the traditional arts and crafts, which on the one hand the use of the main components of mechanized large-scale production of manufactured products, on the other hand hired craftsmen to handle the details [10].

Cultural Aspect. Furniture is the product of daily life activities and is a form of culture, in the traditional culture inheritance, the Ming-style furniture made a very good practical work, they simple, elegant and profound meaning limited decoration, the product has a strong Chinese flavor. Chinese traditional elements vast, rich in meaning, derived blessing, longevity, Paul, Switzerland, Kyrgyzstan and other traditional culture, they are cultural genes of innovation and development of China's furniture industry. Modern furniture products in order to highlight the Chinese characteristics and originality, it is necessary to conduct in-depth research from the perspective of cultural heritage, culture god with furniture form a cross. Only in the cultural level of development 
and innovation in order to effectively combine the traditional and modern, in order to truly create furniture products not only with traditional culture but also reflect the current society.

\section{New Confucianism Style Furniture Design with Virtue and Morality.}

Virtue is an important aspect of Confucianism, which belongs to ethics, humanities category, because it is often linked with love and justice, virtue has become another name of virtue and morality.

In the modern furniture design reflects the benevolence is a people-oriented, it is necessary to pay attention to people's demands in the emotional aspects of traditional culture, but also to meet the needs of the people and cultural life. which objective is to create a combination of modernity and tradition, mechanization and crafts, rationalism and the milk of human kindness, style simple, elegant, lively, rational use of natural materials and prominent characteristic of material, paying attention to the unity of form and function of the products. Prominent in modern furniture industry of righteousness, is to emphasize the people-oriented and achieve harmony between people and things.

If it is said that the furniture structural design needs to consider the strength and balance, process design need to focus on the choice of materials and technical scrutiny, then modeling is more need life meticulous observation and real experience, which is the so-called design in heart and everywhere gain inspiration. Comes from life but higher than life is the essence of art, design principle, and only down to earth to experience life and derive inspiration to create the most meaningful of furniture products, we can really make a design full of virtue and morality.

Take the children bed and the old man's bed for example, due to the different group of physiological and psychological characteristics, children's bed design is highlighted, rich colors, modern styling, strong sense, but the old man's bed should do the appropriate height, color, elegant, traditional styling, soft coverings etc., which is based on real life experiences as a basis for furniture design [11].

In addition, with the rapid development of society, more and more intelligent products began to be filled with people's daily life and intelligent home system has gradually attracted the attention of people. In order to adapt to the intelligent home environment, in the research and development of furniture can be appropriately increased intelligent factors, such as the automatic folding furniture, deformation, discoloration, movement, combination, etc..

\section{Conclusions}

The rapid development of economic active Chinese furniture market, also to the people has brought new cultural values and the art aesthetics, but in terms of creating original products, China has become a serious shortage in furniture industry, which greatly reduces the country's furniture industry the level of competition. In modern society, Chinese traditional culture should be the original force of the furniture industry, only the traditional and modern combine and coordinate development in order for the Chinese furniture industry has injected new vitality, and as a representative of Chinese traditional culture, Confucian classics can provide valuable design ideas for the development of Chinese furniture. Confucianism embodies the idea of nature and the doctrine of the mean and virtue and morality has important implications to China furniture industry, to explore Confucianism and profound cultural connotation and applied to the actual development of furniture products with Chinese characteristics can develop a set of furniture products, and can effectively improve the overall level of China's furniture industry.

\section{References}

[1] Tao Ma, Shuang Zhang. Discourse on Culture Inheritance of Traditional Chinese Furniture by Com-parison between Northern Europe Furnirure and Ming-style Furniture [J]. Packaging engineering Vol.32 No.18 2011. 09. (In Chinese) 
[2] Ling Wang. Modern Funiture Design Inheritance and Development of Chinese Traditional Funiture [J]. Furniture and interior decoration. 2010-2. (In Chinese)

[3] Zhen Han Wu. Study on the furniture style evolution from the PersPective of the traditional design mode of thinking [D].Nanjing Forestry University.2011-6. (In Chinese)

[4] Guan Zhong Liu, Hong Bin Jiang. Chinese ancient design-A series of studies on Cybernetics (the under) [M]. Higher Education Press, 2007-10. (In Chinese)

[5] Huan Jun Zhang, Yao Ting Xie. A book to read Confucian Culture [M]. Zhong hua Book Company, 2012. (In Chinese)

[6] Xiao Chun Wang, Jian Zhou Song. Redesign of Ming and Qing Furniture [J]. Packaging engineering Vol. 31 No.10 2010. 05. (In Chinese)

[7] Jia Lai Pan. Chinese traditional furniture [M].People's Fine Arts Publishing House, 2005. (In Chinese)

[8] Yan Hong Yang, Hai Min Zhang,Jing Rong Sun.Study of Modern Furniture Design Based on Traditional Culture.[J].Journal of Northwest Forestry University.2013,28(1) ; 188-191.(In Chinese)

[9] Ping Li .research on changes and development trend of modern civilian furniture modeling design [D].Northeast Forestry University.2012-04. (In Chinese)

[10]Shen Yu, Xiang Wang.21 century furniture design trends [J].Northeast Forestry University.2001-02. (In Chinese)

[11]Kai Liu. Unity of Diversified Furniture Decoration Style and Humanization Design [J].Art Observation, 2010(3):116. (In Chinese) 